\title{
Organizational Citizenship Behavior and Internal Marketing in Nursing Profession: A Correlational Study
}

\author{
Magda Abd-elbaest Mohamed ${ }^{1}$, Gehan Mohamed Diab ${ }^{2}$ \& Soha Mamdouh El-Kholy ${ }^{3}$ \\ 1. Nursing Educator, El_Bagour secondary technical nursing school, Menofia , Egypt \\ 2. Professor of Nursing Administration, Faculty of Nursing, Menoufia University, Egypt. \\ ${ }^{3}$ Lecturer of Nursing Administration, Faculty of Nursing, Menoufia University. Egypt
}

\begin{abstract}
Background: The majority of labor in healthcare organizations is service-oriented and nurses routinely engage with patients which necessitating nurses' presence and engagement in work roles and voluntarily exceed their duty so, nurses' organizational citizenship behavior is vital resulting in patient satisfaction and high-quality care services. So, effective internal marketing is required to enhance and accelerate organizational citizenship behavior among nurses focusing on nurses' needs to achieve organization mission and goals. The Aim of this study was to determine the association between organizational citizenship behavior and internal marketing of nursing profession. Research design: A descriptive correlational research design was used. Setting: The research was carried out at the Menoufia University Hospital. Sample: A systematic random sample of 400 staff nurses was participated in this study. Tools: Two instruments were used namely: Internal marketing questionnaire and Citizenship behavior in the workplace Scale. Results: There was a strong positive relation between organizational citizenship behaviors and internal marketing among nurses in nursing profession. Recommendation: Conducting a regular workshops, training, and educational programs to increase awareness of all nursing personnel toward OCB and internal marketing and its benefits to nursing work.
\end{abstract}

\section{Keywords: Organizational citizenship behaviors, internal marketing \&Nursing profession}

\section{Introduction}

Health care organizations are facing rapid technological changes which require to be adopted with human resource capital and finance. Due to lack of healthcare organizational resources and funding, downsizing, restructuring and increased job complexity which put the organization in a great challenge to be open to change, team-oriented, proactive, learning organizations and manage human resources to get the staff nurses to be assigned more work than the prescribed job description and contribute extra efforts manifested by organizational citizenship behavior in health care organizations that are encouraged to structurally empower the employees so that a sense of worth could be created in all employees (Kasekende et al. 2020).

Organizational citizenship behavior (OCB) is a subset of organizational behavior carried out by members of the organization without the requirement of roles and positions and is carried out based on individual choice. Individuals' behavior in the workplace is referred to as organizational citizenship behavior which is concerned with carrying out work activities without expecting rewards beyond the command of the organization's chairman without coercion and pressure (Navis, et al. 2020).

Employees will be successful in a health-care organization if they not only do their jobs but also desire to support one another, give advice, contribute actively, provide the greatest services, and properly use the time they have. The atmosphere has a comfortable working connection with a nurse who has organizational citizenship behavior (OCB) (AL-Abrrow, et al. 2020).

Organizational citizenship behavior (OCB) display a multidimensional concept through which positive organizational relevant behaviors of employees in terms of official behaviors, organizational relevant extra-role attitudes, activities, and selfless activities Conscientiousness, sportsmanship, civic virtue, civility, and altruism are the five dimensions that make up OCB. These five dimensions include things like helping coworkers, adhering to corporate standards, not whining, and actively participating in organizational activities. These five dimensions include things like assisting coworkers, adhering to organizational standards, not whining, and actively participating in organizational matters. (Solihin \& Manurung, 2020).

OCB has significant importance in the workplace through various behaviors which include extracurricular activities, assisting coworkers, adhering to workplace standards, and behaving in accordance with corporate policies and procedures are just a few examples. 
As a sort of helping behavior, OCB can be characterized as activities that require a greater level of commitment than spontaneous aid and in which time is freely given to benefit another person, group, or organization. (Jena, 2021).

Organizational citizenship behaviors (OCBs) are critical for continued organizational growth and development; they play a significant role in improving the quality of health care services and facilities required in hospitals to handle patients' cases, as well as improving patient care and morale, facilitating access to health care organizations' goals, and improving their performance. OCBs also have a significant positive influence at the organizational level, increasing productivity, efficiency, lowering expenses, and lowering rates of employee turnover and absenteeism, all of which improve organizational performance. (Chamisa, et al. 2020).

Successful nurse managers persuade staff nurses to emerge voluntary behaviors named organizational citizenship behaviors for the organizations in order to strengthen the responsibility and empower the human resources. In other words, motivating the human resources for empowering them to emerge the organizational citizenship behaviors will be a great challenge of current nurse managers (Griffin et al. 2020).

\section{Internal marketing(IM)}

Internal marketing is a philosophy of treating employees as customers and requiring customeroriented employees to manage all interactive activities in order to create a more efficient internal environment within the organization. It also entails attracting, developing, motivating, and retaining qualified employees through job products that meet their needs. (Kang, 2020).

Internal marketing is a set of actions done by human resource departments in firms to encourage, educate, and train staff so that they can provide better services to clients. External marketing success, according to IM, is contingent on the organization's having motivated, satisfied, and innovative employees to improve the employees' skills to respond to the organization's needs. (Sahibzada et al. 2020).

Internal marketing helps firms produce better customer service by aligning, coordinating, and motivating personnel, which has a subsequent effect on three primary areas or components: comprehension of organizational vision and values, quality delinquency, and customer satisfaction. (Pohjalainen, 2021). Internal marketing involves a number of activities multi-dimensional construct, which are; Employee-oriented behaviors, Communication management, Employee training, Job description, Fair reward, Organizational support,
Supervisor support, Empowerment, Employment security (Bavik, 2020).

Internal marketing is a strategy aimed at attracting, developing, retaining, and coordinating personnel across departments, with the goal of increasing employee happiness while improving service quality and satisfaction for external customers. Also IM enhances the productivity of the employees and patient safety which increases salaries which is important for the public non-profit healthcare system (Yeum et al. 2020).

Marketing is an organization's whole system of interactional activities for planning, pricing, promoting, and distributing need-satisfying items to current and potential customers.

That is heavily impacted by quality management and service marketing, which highlights the need and necessity of producing quality in all service-delivery operations, taking customers and internal stakeholders into account. (Gabbianelli \& Pencarelli, 2021).

Internal marketing management practices are a great way to increase creativity within organizations. It is also an attractive system for employees who facilitate collaboration, commitment, interaction, creativity, and contributing which lead to an optimal citizenship behavior, as well as contributes in achieving the organization's goals and sustainability. Therefore, it is necessary to study the internal marketing management practices in organizations that have created a fertile environment which can find recent ideas to get the desired goals, safety of achieving employees' objectives and their reputation in the local market in general (Boonparn et al. 2020).

Successful marketing management requires Nurse Managers to be aware of and implement a specified set of activities. Creating marketing plans and strategies: Identifying possible prospects and core capabilities, as well as developing concrete marketing plans that detail the marketing strategy and methods for the future, is a critical effort. Whatever role marketing strategy plays in an organization's success, (Adeola et al. 2020).

\section{Significance of the study:}

Health care setting are facing rapid technological changes which demands taking challenge of induction and diversion of values added to heath service customer such as internal marketing activities and organizational citizenship behavior which enable nurses to provide high quality health care service for achieving high level of organization productivity and profitability. As a result, the current study was done to determine the association between corporate citizenship behavior and nursing profession internal marketing. 
Aim of the Study:

The aim of this study was to determine the association between corporate citizenship behavior and nursing profession internal marketing at Menoufia University Hospitals at Shebin El-Kom.

\section{Research questions:}

1. What are staff nurses' perception of organizational citizenship behavior and internal marketing?

2. Is there a relationship between organizational citizenship behavior and internal marketing among nurses in nursing profession?

\section{Methods}

\section{Research Design}

A descriptive correlational research design was used for conducting this study

\section{Setting}

The study was conducted at Menoufia University Hospital, Menoufia governorate affiliated to the Ministry of Higher Education, Egypt.

\section{Participants}

A systematic random sample $(n=400)$ of staff nurse working at (Intensive care unit, operating theaters, emergency department, oncology, medical-surgical department, and hemodialysis unit) at Menoufia University Hospital.

Instruments for data collection: Two instruments were used to collect data, which are:

Instrument I: Internal marketing questionnaire: It was developed by Khtab, (2014) and adapted by the investigator to assess the availability of utilization of internal marketing elements among staff nurses, which consists of two parts:

Part 1: includes socio-demographic characteristics of staff nurses (age, education, marital status, department, years of experience and work hours).

Part 2: This part consists of 73 items, which are subdivided into nine interrelated internal marketing parts namely: (Employee-oriented behaviors, Communication management, Employee training, Job description, fair reward, Organizational support, Supervisor support, Empowerment, Employment security).

Scoring system; the responses based on three point Likert scale ranging from 3: frequently utilized, 2: sometimes utilized 1 , rarely utilized. The total score for the items of the questionnaire ranged from 73 to 215. Each element's scores were added together and converted to a percentage. The high level of the availability of utilization of internal marketing was more than $75 \%$, moderate score ranged from $60 \%$ $75 \%$ and low level is less than $60 \%$. Cronbach's $\alpha$ is (0.915).
Instrument II: Organizational Citizenship behavior Scale: which was developed by LePine, Erez \& Johnson, (2002) and modified by the investigator. The scale was used to assess nurses' perception of organizational citizenship behavior and consists of 24 items, which was subdivided into five dimensions: (Altruism, generalized compliance, civic virtue, courtesy, and sportsmanship).

Scoring system; the responses was based on three points Likert scale ranging from 3, usually, 2 sometimes and 1 rarely. The total possible score for the items of the questionnaire ranged from 24 to 72 . Each element's scores were added together and converted to a percentage. More than $75 \%$ of nurses' perception of organizational citizenship is considered high, moderate percent score ranged from $60 \%-75 \%$ and low in less than $60 \%$. Cronbach's $\alpha$ of the overall OCB $(\alpha=0.757)$ and Cronbach's $\alpha$ for the 5 subscales ranges from (0.663 to 0.802$)$.

\section{Ethical considerations}

The Ethics Committee of Menoufia University's Faculty of Nursing gave their approval. Prior to data collection, participants' consent to participate in the study was obtained, ensuring data privacy and confidentiality. Participants were guaranteed anonymity.

\section{Pilot Study}

A pilot research was conducted on $10 \%$ of the nurses $(n=40)$ who were not included in the study, and necessary changes and clarifications to some questions were made.

\section{Statistical analysis}

The software utilized was the Statistical Package for the Social Sciences (SPSS v. 19). To describe and summaries the data, descriptive statistics (i.e., means and standard deviations) were used. Chi-square test $(\chi 2)$ is used to investigate the relationship between two qualitative variables.

Spearman correlation is a method of demonstrating a relationship between two continuous variables that are not regularly distributed. A p-value of $\mathrm{P}<0.005$ was considered significant. 


\section{Results}

Table (1): Personal characteristics of the studied staff nurses $(N=400)$ :

\begin{tabular}{|c|c|c|}
\hline Socio demographic characteristics & No. & $\%$ \\
\hline \multicolumn{3}{|l|}{ Age/ year: } \\
\hline$<33$ years & 202 & 50.5 \\
\hline$>33$ years & 198 & 49.5 \\
\hline \multicolumn{3}{|c|}{$\begin{array}{c}\text { Range: } 20-35 \\
\text { Mean } \pm \text { SD: } 32.3 \pm 2.83\end{array}$} \\
\hline \multicolumn{3}{|l|}{ Marital status: } \\
\hline Married & 353 & 88.3 \\
\hline Single & 47 & 11.7 \\
\hline \multicolumn{3}{|l|}{ Qualifications: } \\
\hline Secondary technical nursing school & 12 & 3.0 \\
\hline Associated degree in nursing & 41 & 10.3 \\
\hline Bachelor degree in nursing & 320 & 80.0 \\
\hline Post graduate & 27 & 6.7 \\
\hline \multicolumn{3}{|l|}{ Years of experience: } \\
\hline $1-5$ years & 57 & 14.2 \\
\hline $6-10$ years & 175 & 43.8 \\
\hline $11-20$ years & 168 & 42.0 \\
\hline \multicolumn{3}{|l|}{ Work hours: } \\
\hline 8 hours & 352 & 88.0 \\
\hline 12 hours & 48 & 12.0 \\
\hline
\end{tabular}

Table (2): Mean score of organizational citizenship behavior among staff nurses $(\mathrm{N}=400)$ :

\begin{tabular}{|l|c|c|c|}
\multirow{2}{*}{\multicolumn{1}{|c|}{ Studied variables }} & \multicolumn{2}{c|}{ Range } & \multirow{2}{*}{ Mean \pm SD } \\
\cline { 2 - 3 } & Min & Max & $12.6 \pm 2.63$ \\
\hline Organizational citizenship behaviors(OCB) & 15 & $12.7 \pm 0.94$ \\
\hline Altruism & 5 & 15 & $8.5 \pm 2.17$ \\
\hline Generalized compliance & 5 & 12 & $13.5 \pm 1.23$ \\
\hline Civic virtue & 4 & 15 & $7.06 \pm 2.06$ \\
\hline Courtesy & 5 & 15 & $\mathbf{5 4 . 3} \pm \mathbf{8 . 3 3}$ \\
\hline Sportsmanship & 5 & $\mathbf{7 2}$ & \\
\hline Total OCB & $\mathbf{2 4}$ & \multicolumn{2}{c|}{} \\
\hline
\end{tabular}

Table (3): Mean score of internal marketing among the studied staff nurses $(\mathrm{N}=400)$

\begin{tabular}{|l|c|c|c|}
\hline \multicolumn{1}{|c|}{ Studied variables } & \multicolumn{2}{c|}{ Range } & \multirow{2}{*}{ Mean \pm SD } \\
\cline { 2 - 3 } & Min & Max & \\
\hline Internal marketing( dimensions) & 7 & 21 & $16.4 \pm 3.76$ \\
\hline Employees- oriented behavior & 6 & 18 & $15.5 \pm 3.20$ \\
\hline Communication management & 7 & 21 & $17.6 \pm 3.34$ \\
\hline Employee training & 8 & 24 & $21.6 \pm 4.72$ \\
\hline Job description & 11 & 33 & $24.1 \pm 4.72$ \\
\hline Fair reward & 5 & 15 & $9.07 \pm 2.46$ \\
\hline Organizational support & 15 & 45 & $35.6 \pm 6.64$ \\
\hline Supervisor support & 4 & 12 & $8.01 \pm 2.19$ \\
\hline Empowerment & 9 & 27 & $19.9 \pm 4.04$ \\
\hline Employments security & $\mathbf{7 3}$ & $\mathbf{2 1 9}$ & $\mathbf{1 6 8 . 2} \pm \mathbf{3 3 . 8}$ \\
\hline Total internal marketing & \multicolumn{3}{|c|}{} \\
\hline
\end{tabular}


Table (4): Correlation between organizational citizenship behavior and internal subscales among staff nurses $(\mathrm{N}=\mathbf{4 0 0})$

\begin{tabular}{|c|c|c|c|c|c|c|c|}
\hline \multirow{2}{*}{\multicolumn{2}{|c|}{ Internal marketing }} & \multicolumn{6}{|c|}{ Organizational citizenship behavior } \\
\hline & & \multirow{2}{*}{$\begin{array}{c}\text { Altruism } \\
-0.092\end{array}$} & \multirow{2}{*}{$\begin{array}{c}\begin{array}{c}\text { Generalized } \\
\text { compliance }\end{array} \\
-0.029\end{array}$} & \multirow{2}{*}{$\begin{array}{c}\begin{array}{c}\text { Civic } \\
\text { virtue }\end{array} \\
-0.143\end{array}$} & \multirow{2}{*}{$\begin{array}{c}\text { Courtesy } \\
-0.175\end{array}$} & \multirow{2}{*}{$\begin{array}{c}\text { Sportsmanship } \\
0.314\end{array}$} & \multirow{2}{*}{$\frac{\text { Total }}{0.024}$} \\
\hline Employees- & $\mathrm{R}$ & & & & & & \\
\hline oriented behavior & $\mathrm{P}$ value & 0.065 & 0.561 & $0.004 * *$ & $0.001 * *$ & $0.001 * *$ & 0.626 \\
\hline \multirow{2}{*}{$\begin{array}{l}\text { Communication } \\
\text { management }\end{array}$} & $\mathrm{R}$ & -0.162 & -0.243 & 0.056 & -0.024 & 0.222 & 0.004 \\
\hline & $\mathrm{P}$ value & $0.001 * *$ & $0.001 * *$ & 0.260 & 0.643 & $0.001 * *$ & 0.930 \\
\hline \multirow{2}{*}{ Employee training } & $\mathrm{R}$ & 0.085 & 0.337 & -0.259 & 0.052 & -0.067 & -0.055 \\
\hline & $\mathrm{P}$ value & 0.088 & $0.001 * *$ & $0.001 * *$ & 0.299 & 0.182 & 0.268 \\
\hline \multirow{2}{*}{ Job description } & $\mathrm{R}$ & 0.046 & -0.223 & 0.055 & 0.321 & 0.193 & 0.123 \\
\hline & $\mathrm{P}$ value & 0.360 & $0.001 * *$ & 0.271 & $0.001 * *$ & $0.001 * *$ & $0.014 *$ \\
\hline \multirow{2}{*}{ Fair reward } & $\mathrm{R}$ & -0.261 & 0.054 & -0.291 & -0.140 & -0.135 & 0.249 \\
\hline & $\mathrm{P}$ value & $0.001 * *$ & 0.278 & $0.001 * *$ & $0.005^{* *}$ & $0.007 * *$ & $0.001 * *$ \\
\hline \multirow{2}{*}{$\begin{array}{l}\text { Organizational } \\
\text { support }\end{array}$} & $\mathrm{R}$ & -0.471 & -0.017 & -0.187 & 0.077 & 0.282 & -0.094 \\
\hline & $\mathrm{P}$ value & $0.001 * *$ & 0.736 & $0.001 * *$ & 0.125 & $0.001 * *$ & 0.060 \\
\hline \multirow{2}{*}{ Supervisor support } & $\mathrm{R}$ & -0.009 & 0.023 & 0.081 & -0.110 & 0.519 & 0.285 \\
\hline & $\mathrm{P}$ value & 0.857 & 0.644 & 0.105 & $0.027 *$ & $0.001 * *$ & $0.001 * *$ \\
\hline \multirow{2}{*}{ Empowerment } & $\mathrm{R}$ & 0.134 & -0.240 & 0.495 & 0.077 & 0.122 & 0.370 \\
\hline & $\mathrm{P}$ value & $0.007 * *$ & $0.001 * *$ & $0.001 * *$ & 0.124 & $0.015^{*}$ & $0.001 * *$ \\
\hline \multirow{2}{*}{$\begin{array}{l}\text { Employments } \\
\text { security }\end{array}$} & $\mathrm{R}$ & 0.034 & -0.022 & 0.175 & -0.322 & -0.243 & -0.033 \\
\hline & $\mathrm{P}$ value & 0.494 & 0.661 & $0.001 * *$ & $0.001 * *$ & $0.001 * *$ & 0.515 \\
\hline \multirow{2}{*}{ Total } & $\mathrm{R}$ & 0.178 & -0.049 & -0.096 & -0.083 & 0.430 & 0.785 \\
\hline & $\mathrm{P}$ value & $0.001 * *$ & 0.400 & 0.054 & 0.098 & $0.001 * *$ & $0.001 * *$ \\
\hline
\end{tabular}

Significance level at $p$ value $<0.05$

**High significant

Table (5): Relationship between total internal marketing, organizational citizenship behavior and socio demographic characteristics of staff nurses $(N=400)$.

\begin{tabular}{|c|c|c|c|c|}
\hline Socio demographic characteristics & $\begin{array}{c}\text { IM } \\
\text { Mean } \pm \text { SD }\end{array}$ & P value & OCB & $P$ value \\
\hline $\begin{array}{l}\text { Age / years } \\
<33 \\
>33 \\
\end{array}$ & $\begin{array}{l}162.5 \pm 36.1 \\
174.1 \pm 30.2 \\
\end{array}$ & $\begin{array}{l}\mathrm{U}=3.17 \\
0.002 * *\end{array}$ & $\begin{array}{l}52.8 \pm 9.04 \\
55.8 \pm 7.24 \\
\end{array}$ & $\begin{array}{c}\mathrm{U}=3.38 \\
0.001 * *\end{array}$ \\
\hline $\begin{array}{l}\text { Marital state } \\
\text { Married } \\
\text { single }\end{array}$ & $\begin{array}{l}170.1 \pm 33.5 \\
154.5 \pm 32.7\end{array}$ & $\begin{array}{c}\mathrm{U}=3.01 \\
0.003^{* *}\end{array}$ & $\begin{array}{l}54.7 \pm 8.24 \\
51.5 \pm 8.55\end{array}$ & $\begin{array}{c}\mathrm{U}=2.85 \\
0.004 * *\end{array}$ \\
\hline $\begin{array}{l}\text { Educational level } \\
\text { Secondary technical nursing school. } \\
\text { Associated degree in nursing. } \\
\text { Bachelor degree in nursing. } \\
\text { Post graduate. }\end{array}$ & $\begin{array}{r}147.5 \pm 47.2 \\
160.3 \pm 37.9 \\
180.6 \pm 28.2 \\
168.1 \pm 37.9\end{array}$ & $\begin{array}{c}\mathrm{K}=9.98 \\
0.019^{*}\end{array}$ & $\begin{array}{l}49.5 \pm 12.5 \\
52.2 \pm 9.47 \\
56.7 \pm 6.60 \\
54.3 \pm 8.16\end{array}$ & $\begin{array}{l}\mathrm{K}=10.2 \\
0.016^{*}\end{array}$ \\
\hline $\begin{array}{l}\text { Years of experience } \\
(1-5 \text { years }) \\
(6-10 \text { years }) \\
(11-20 \text { years }) \\
\end{array}$ & $\begin{array}{l}155.7 \pm 38.5 \\
166.6 \pm 33.7 \\
174.2 \pm 30.9 \\
\end{array}$ & $\begin{array}{l}\mathrm{K}=11.1 \\
0.004 * *\end{array}$ & $\begin{array}{l}50.9 \pm 9.70 \\
53.9 \pm 8.24 \\
55.9 \pm 7.53\end{array}$ & $\begin{array}{l}\mathrm{K}=11.9 \\
0.002 * *\end{array}$ \\
\hline $\begin{array}{l}\text { Years of experience in current } \\
\text { department } \\
(1-5 \text { years }) \\
(6-10 \text { years }) \\
(11-20 \text { years }) \\
\end{array}$ & $\begin{array}{l}168.3 \pm 33.6 \\
168.2 \pm 34.0 \\
168.0 \pm 34.5 \\
\end{array}$ & $\begin{array}{c}\mathrm{K}=0.001 \\
0.998\end{array}$ & $\begin{array}{l}54.3 \pm 8.26 \\
54.3 \pm 8.37 \\
54.2 \pm 8.59\end{array}$ & $\begin{array}{c}\mathrm{K}=0.012 \\
0.994\end{array}$ \\
\hline $\begin{array}{l}\text { Work hours } \\
8 \text { hours } \\
12 \text { hours }\end{array}$ & $\begin{array}{l}164.4 \pm 32.7 \\
196.4 \pm 27.9\end{array}$ & $\begin{array}{c}\mathrm{U}=6.90 \\
0.001 * *\end{array}$ & $\begin{array}{l}53.2 \pm 7.92 \\
61.8 \pm 7.41\end{array}$ & $\begin{array}{c}\mathrm{U}=6.88 \\
0.001 * *\end{array}$ \\
\hline
\end{tabular}


Table (1): Shows personal characteristics of staff nurses. As shown in this table about half $(50.5 \%)$ of nurses had less than 33 years with mean score $(32.3 \pm 2.83)$ year. The highest percentage $(80 \%)$ of nurses had Bachelor degree in nursing and nearly to half $(43.8 \%)$ of the staff nurses had (6-10) experience years. Furthermore, slightly less than half $(48.0 \%)$ of them had had (6-10) experience years in the current department and the majority (88\%) of staff nurses working 8 work hours/day.

Table (2): Illustrates the mean score of organizational citizenship behaviors and its subscales among staff nurses. It shows that the highest mean of organizational citizenship behaviors scale was courtesy with $(13.5 \pm 1.23)$ while sportsmanship had the lowest mean score $(7.06 \pm 2.06)$. The total organizational citizenship behaviors mean was (54.3 \pm 8.33$)$.

Table (3): Illustrates the mean score of internal marketing and its dimensions among staff nurses. It shows that the highest internal marketing dimension was supervisor support with $(35.6 \pm 6.64)$. While empowerment had the lowest mean score $(8.01 \pm 2.19)$. The total internal marketing mean was (168.2 \pm 33.8$)$.

Table (4): Shows the correlation between organizational citizenship behavior and internal subscales among staff nurses. There was a substantial positive relationship between organizational citizenship conduct and job description $(\mathrm{r}=0.123)$, fair reward $(\mathrm{r}=0.249)$, supervisor support $(\mathrm{r}=0.285)$, empowerment $(\mathrm{r}=0.370)$ and total internal marketing $(\mathrm{r}=0.785)$ where $\mathrm{p}>0.05$. While there was no significant correlation between organizational citizenship behavior with employees- oriented behavior, communication management, employee training, organizational support and employments security.

Table (5): Explains the relationship between total internal marketing, organizational citizenship behavior and socio demographic characteristics of staff nurses. It showed that age, marital state, educational level, years of experience and work hours were significantly increased among total internal marketing than organizational citizenship behavior $(\mathrm{P}<0.05)$. On the other hand, there was nonsignificant difference between internal marketing and organizational citizenship behavior regarding years of experience in the current department $(\mathrm{P}=0.994)$.

\section{Discussion}

Care of human resource is needed in each organization, which is considered its main success, which is one of the primary components in establishing a competitive edge and creating sustainable value for an organization. Internal marketing is a strategy that treats employees as the most organization' significant asset and internal customers, claiming that by meeting internal customers' needs for achieving success. (Kryscynski et al. 2021). Because of creating crucial job satisfaction and organizational productivity, organizational citizenship behavior is a desirable for health care organizations and are found to be important in promoting higher level of organizational productivity, quality, and

effectiveness

(Abdulmuhsin et al. 2021).

Internal marketing methods and techniques have an impact on employee retention and citizenship behavior. Where their in-role and extra-role behaviors improve. So, internal marketing has an impact on organizational citizenship behavior, which in turn enhances overall performance. (Boonparn et al. 2020).

This study aimed at determining organizational citizenship behaviors and its relationship to internal marketing of nursing profession as perceived by staff nurses. The present study showed that the highest organizational citizenship behaviors scale was courtesy while, the lowest organizational citizenship behaviors scale was sportsmanship with.

From the researcher point of view, the high level of OCBs may be due to nurses are conscious about changes affecting their work. While, low sportsmanship may be due to that nurses when they were willing to tolerate expected inconvenience and getting work without complaint they ignored some issues although their conception of positive work.

This result is agreed with Shrestha, \& Subedi, (2020) who mentioned that staff nurses have high and moderate level of OCBs among all its components and among these five components of OCB, courtesy consists of the highest mean score, which refers to high OCB. While, Ozluk \& Baykal, (2020) studied organizational citizenship behavior among nurses reported that courtesy OCBS' subscale was the lowest score.

Regarding organizational citizenship behaviors among staff nurses. It showed that the majority of the staff nurses had high level of total organizational citizenship behaviors. From researcher view this may be due to the overall performing actions among nurses through helping others in task doing, following hospital rules, and acting as volunteer in doing extra activities.

Meniado, (2021) studied organizational citizenship behavior and emotional intelligence of teachers in Saudi Arabia agreed on our study and mentioned that there was a very high level of organizational citizenship behaviors among the respondents. Also, Nawaf, et al. (2020) studied the effect of high commitment work system on improving OCBs, and 
reported a very high level of OCBs among study sample. On the contrary Mohamed et al. (2018) investigate the link between nurse quality of life and organizational citizenship behavior and mentioned that the majority of them had a low level of organizational citizenship behaviors.

The present study showed that the highest internal marketing dimension was supervisor support. While the lowest internal marketing dimension is empowerment. From the researcher point of view this may be due to nurses' supervisors provide frequent support to nurses' contributions, efforts, and actively listen to their problem and solving it. Also, allow flexible work arrangement and recognizing nurses' task accomplishments. While, low empowerment may be due to nurses are not allowed to try their own ideas and developing new ways for doing their job.

In the same line Mohammad et al. (2020) investigated the influence of internal marketing practices on the employees' intention to leave and indicated that employees evaluated their supervisor support as the highest level. While, empowerment was the lowest level. On the other hand, Abo Soliman et al. (2020) studied the assessment of availability of internal marketing elements and revealed that the communication element is the highest one among all internal customers, followed by supervision and scientific research support.

The present study showed that staff nurses reported high level of internal marketing. From researcher point of view. This may be due to hospital trial to enhance service quality for customer satisfaction through internal marketing approaches. In which hospitals exerts efforts for training, rewarding, and managing its human resources for better service providing.

In agreement, with Jahan, \& Allaymoun, (2020) who studied the effect of training, motivation and internal communication on the performance of employees and showed high internal marketing level between employees and all of the respondents indicated that internal marketing practices are contributing to employee's performance. On the other hand the study performed by Gomaa \& Mohamed (2020) about formulation of internal marketing strategy to improve nurses' work engagement and demonstrated that, about half of total internal marketing was low and internal marketing practices not effectively applied in health organizations.

There was a substantial positive link between organizational citizenship behavior and job description, fair reward, supervisor support, empowerment and total internal marketing. While there was no significant correlation between organizational citizenship behavior with employeesoriented behavior, communication management, employee training, organizational support and employments security ( $\mathrm{p}>0.05)$.

In the same line with Santoso et al. (2020) who investigated the role of job satisfaction and organizational citizenship behavior on performance and concluded that job satisfaction and organizational citizenship behavior have a positive and significant effect on employees' performance. Besides, job description has a positive and significant effect on organizational citizenship behavior. Also, Sheeraz et al. (2020) studied moderating role of leader-member exchange between the relationship of organizational justice and organizational citizenship behavior agreed with our findings, revealing that distributive justice and procedural justice are linked to altruism, courtesy, and civic virtues, while interactional justice is only linked to courtesy.

Our results are in line with Motalebi \& Marşap, (2020) who studied the role of job satisfaction, and organizational commitment as a determinant of organizational citizenship behavior among the workers of welfare organization and showed that the relationship between the total score of job satisfaction and dimensions of physical condition leadership style, organizational atmosphere, job variety, with organizational citizenship behavior, showed that high score in these variables is associated with a high score in organizational citizenship behavior. Also, higher relation pay tends to increase satisfaction and all related to high OCBs in the organization. Also, Kose et al. (2019) studied factors affecting administrative and organizational success in the turkey's forestry and examined association between superiors and subordinates in organizations. Who revealed that the degree of employees' openness to communicate with their superiors is significantly correlated with OCB.

Also, in the same line Abdulrab et al. (2020) studied the impact of transformational leadership and psychological empowerment on organizational citizenship Behavior and mentioned that psychological empowerment significantly influenced the participants' organizational citizenship behavior and added that psychological empowerment is positively related to OCB). Also, Helmy et al. (2019) studied linking psychological empowerment, knowledge sharing, and employees' innovative behavior showed that psychological empowerment has a significant influence on OCB.

Our result agreed with Thomas \& Rodrigues, (2020) who studied internal marketing and brand promise delivery of Indian public sector and mentioned that internal marketing practices had a significant effect on organizational citizenship behavior. Moreover, Norris \& Porter, (2021) studied the influence of spirituality in the workplace and perceived 
organizational support on organizational citizenship behaviors for strategic success and shown that civic virtue is influenced by perceived organizational support, which is an organizationally driven OCB.

The present study showed that, age, marital state, educational level, years of experience and work hours were significantly increased among total internal marketing than organizational citizenship behavior. On the other hand, there was non-significant difference between internal marketing and organizational citizenship behavior regarding years of experience in the current department. From researcher point of view their was positive correlation saw as related to increase the age and experience of nurses in their work, their efficiency in giving nursing care which back to the length of work in the hospital.

In congruence with our results Ajlouni et al. (2020) studied the impact of employees' gender and age on organizational citizenship behavior using a fuzzy approach and reported a substantial correlations between the genders of managers and their educational levels and OCB. Also, Atta \& Khan, (2020) studied relationship between perceived transformational leadership and Organizational Citizenship Behavior in University Teaching Faculty agreed with our results and reported that all variables including gender and age, have a substantial impact on OCB. Additionally, Altuntaş, et al (2020) about the effect of ethical work climate on the organizational citizenship behavior of academic nurses and stated that employee variables such as age, work position, institutional experience, and professional traits were found to have similar strong OCB relationships. The result is in congruence with the study performed by Prabowo, (2020) about organizational citizenship behavior, organizational climate, and employee performance and found that all demographic parameters (sex, marital status, academic qualification, kind of occupation, age, salary, type of employment, department, job position, and length of employment) can influence OCB,

Moreover, the study is agreed with Aderibigbe et al. (2019) who studied the effect of psychosocial factors on organizational citizenship behavior among graduate employees in Nigeria and showed that marital status had a statistical link to OCB. Additionally Mahnaz et al. (2013) studied the relationship between OCB and demographic characteristics (sex, marital status, academic qualification, type of profession, salary and wages, ethnicity, job position, and duration of employment) agreed on our results and revealed that all demographic characteristics, with the exception of ethnicity, had a significant effect on OCB.

On the other hand Nawafleh\& Alsafadi, (2020) studied the effect of a high-commitment work system on improve organization citizenship behavior and reported that there is insignificant differences in respondents about OCB depending on demographic variables(Gender, Qualification, Experience, and Job description).

Also, in contrast with the study performed by Badawy et al. (2017) to evaluate and compare the impact of demographics on OCB in Egypt, and found no significant association between gender, age, years of experience, level of education, and Egyptian employees' OCB. Contrarily, with the study conducted by Banan (2017) on staff nurses' perceptions of organizational support, psychological empowerment, and intention to stay at a specific hospital, and confirmed that there was no statistically significant relationship between demographic variables such as age, gender, academic or degree level.

Additionally, Abed \& Elewa, (2016) studied the relationship between organizational support, work engagement and organizational citizenship behavior as perceived by staff nurses at different hospitals disagreed on our results stating that there was insignificant statistical difference between nurses' perception of citizenship behavior and their age, marital status, years of experience, while there was statistical significant relation with working unite, working hospital and citizenship behavior. Moreover, the study in contrast with the study conducted by Uzonwanne, (2014) about organizational citizenship behavior and demographic factors and revealed that there were no significant relationship between OCB with educational level and marital status.

\section{Conclusion}

In the light of the present study, it can be concluded that the staff nurses had high level of organizational citizenship behaviors and also reported high level of utilization internal marketing elements. Additionally, there is a highly statistical significant positive correlation between organizational citizenship behaviors with total internal marketing. Regarding demographic characteristics, age, marital state, educational level, years of experience and work hours were significantly increased among total internal marketing than organizational citizenship behavior. While, there was non-significant difference between internal marketing and organizational citizenship behavior regarding years of experience in the current department.

\section{Recommendations}

1. Increase awareness of all nursing personnel toward OCBs and internal marketing through attending regular workshops and conferences. 
2. Creating positive organizational climate culture to tolerate employees' work problem and enhancing OCBs based on common values.

3. Enriching and refreshing newly appointed nurses' knowledge and skills about OCBs and internal marketing throughout continuous updated training programs.

4. Encourage staff nurses to practice and apply OCBs as an integral part of their daily work activities.

5. Internal marketing principles should be integrated into nursing job performance criteria at all levels of practice.

6. Nurse managers should create positive and motivational climate for increasing nurses OCBs.

\section{References:}

- Abdulmuhsin A, Zaker R, \& Asad M. (2021): How exploitative leadership influences on knowledge management processes: the moderating role of organizational citizenship behavior. International Journal of Organizational Analysis. (Issue(s) available: 71 - From Volume: 13 Issue: 1, to Volume: 29 Issue: 2) https://doi.org/10.1108/IJOA-09-2020-2424.

- Abdulrab M, Zumrah A, Alwaheeb M, AlMamary Y, \& Al-Tahitah A. (2020): The Impact of Transformational Leadership and Psychological Empowerment on Organizational Citizenship Behaviors: A PLS-SEM Approach. Journal of Critical Reviews, 7(9), 908-917.

- Abed F \& Elewa A (2016): The relationship between organizational support, work engagement and organizational citizenship behavior as perceived by staff nurses at different hospitals. Journal of Nursing and Health Science, 5(4), 113-123.

- Abed F \& Elewa A (2016): The relationship between organizational support, work engagement and organizational citizenship behavior as perceived by staff nurses at different hospital. Journal of Nursing and Health Science, 5(4), 113-123.

- Abo Soliman A, El-sayed N, Ibrahim S, Inany E. \& Ibrahim R (2020): Development of an Internal Marketing Strategy for Faculty of Nursing at Port Said University. Port Said Scientific Journal of Nursing, 7(2), 97-113.

- Adeola O, Hinson R, \& Evans O (2020): Social media in marketing communications: A synthesis of successful strategies for the digital generation. In Digital Transformation in Business and Society (pp. 61-81). Palgrave Macmillan, Cham.

- Aderibigbe J, Nwokolo E, \& Oluwole $O$ (2019): Effect of psychosocial factors on organizational citizenship behavior among graduate employees in Nigeria. Economics \& Sociology, 12(1), 155-367.
- Ajlouni W, Kaur G, \& Alomari S (2020): The Impact of Employees' Gender and Age on Organizational Citizenship Behavior Using a Fuzzy Approach. Social Science Computer Review, 0894439320971234.

- Ali S (2017): Internal Marketing and Organizational Citizenship Behavior: A comparative study. Department of Nursing Administration, Faculty of Nursing, Mansoura University; P (1).

- Altuntaş S, Seren S, Sokmen S, Kantek F, Ozturk H, \& Baykal U (2020): The effect of ethical work climate on the organizational citizenship behavior of academic nurses. International Nursing Review. Volume 68, Issue1, https://doi.org/10.1111/inr.12622.

- Atta M \& Khan M (2020): Relationship between Perceived Transformational Leadership and Organizational Citizenship Behavior in University Teaching Faculty. Pakistan Journal of Social and Clinical Psychology, 18(2), 32-39.

- Badawy T, Trujillo J, \& Magdy M (2017): The demographics' effects on organizational culture, organizational citizenship behavior and job satisfaction: Evidence from Egypt and Mexico. Business and Management Research, 6(28). Doi: 10.5430/ bmr.v6n1p28

- Badawy T, Trujillo J, \& Magdy M (2017): The demographics' effects on organizational culture, organizational citizenship behavior and job satisfaction: Evidence from Egypt and Mexico. Business and Management Research, 6(28). Doi: 10.5430/ bmr.v6n1p28

- Banan S (2017): Perceived organizational support, psychological empowerment and intention to stay among staff nurses at a selected hospital. International journal of Nursing Didactics, 7(3), 42-50.

- Bavik A (2020): A systematic review of the servant leadership literature in management and hospitality. International Journal of Contemporary Hospitality Management. Vol. 32 No. 1, 2020 pp. 347-382, DOI :10.1108/IJCHM-10-2018-0788

- Boonparn C, Rurkwararuk W, Pooncharoen N, \& Leamprecha $\mathbf{N}$ (2020): The Relationship of Schwartz's Basic Individual Values with Internal Marketing, Brand Citizenship Behavior, and Organizational Citizenship Behavior: A Case Study of Call-Centre Staff of Credit Card Issuers in Thailand. Humanities, Arts and Social Sciences Studies) (Former name silpakorn university journal of social sciences, humanities and arts), 399-426.

- Chamisa S, Mjoli T, \& Mhlanga T (2020): Psychological capital and organizational citizenship behavior in selected public hospitals in the Eastern Cape Province of South Africa. SA Journal of Human Resource Management, 18, 12. 
- DaSilva M, Valente M, Petroli A, Detoni D, \& Milan G (2020): Perceived quality of built environment, service, satisfaction and value in use, in the context of residential buildings. Journal of Facilities Management.Vol. 18 No. 4, pp. 451468. https://doi.org/10.1108/JFM-05-2020-0032.

- Gabbianelli L \& Pencarelli T (2021): Exploring some marketing practices in management consulting firms: evidence from small service firms in Italy. The TQM Journal. Vol. ahead-of-print No. ahead-of print. https://doi.org/10.1108/TQM-122019-0308

- Gomaa O \& Mohamed A (2020): Formulation of Internal Marketing Strategy to Improve Nurses' Work Engagement. Assiut Scientific Nursing Journal, 8(20.00), 249-256.

- Griffin R, Phillips J, Gully S, Creed A, Gribble L, \& Watson M (2020): Organizational Behavior: Engaging People and Organizations. Cengage AU. $1^{\text {st }}$ edition, ISBN: 0170440028, 9780170440028, pp (512)

- Hadi A, Krar M, Hasan O, \& Abbas S (2020): The dark triad and organizational citizenship behavior in health care: The moderating role of positive emotions. FEATURE ARTICLE Journal Wiley Periodicals, Inc;39(5):6-17 P.p7

- Helmy I, Adawiyah W, \& Banani A (2019): Linking psychological empowerment, knowledge sharing, and employees' innovative behavior in SMEs. The Journal of Behavioral Science, 14(2), 66-79.https://doi.org/10.1186/1478-4491-2-3

- Jahan N \& Allaymoun M (2020): The Effect of Training, Motivation and Internal Communication on the Performance of Employees at Jordanian Islamic Banks. Journal of Business and Management Studies, 2(2), 16-23.

- Jena L (2021): Does workplace spirituality lead to raising employee performance? The role of citizenship behavior and emotional intelligence. International Journal of Organizational Analysis. Vol. ahead-of-print No. ahead-ofprint. https://doi.org/10.1108/IJOA-06-2020-2279

- Kang C (2020): The Effect of Hospital Internal Marketing on Nurses' Job Satisfaction and Customer Orientation. Journal of the Korea Academia-Industrial cooperation Society, 21(9), 321-330.

- Kasekende F, Nasiima S, \& Otengei S (2020): Strategic human resource practices, emotional exhaustion and OCB: the mediator role of personorganization fit. Journal of Organizational Effectiveness: People and Performance. Vol. 7 No. 3, pp. 275-295.

- Kose M, Daşdemir I, Yurdakul S, \& Yildirim H (2019): Factors affecting administrative and organizational success in the turkey's forestry. Applied ecology and environmental research, 17(4), 8713-8735.

- Kryscynski D, Coff R, \& Campbell B (2021): Charting a path between firm-specific incentives and human capital-based competitive advantage. Strategic Management Journal, 42(2), 386-412.

- Mahnaz M, Mehdi M, Jafar K, \& Abbolghasem P (2013): The Effect of Demographic Characteristics on Organisational Citizenship Behaviour in the Selected Teaching Hospitals in Tehran. African Journal of Business Management, 7, 3324- 3331

- Meniado J (2021): Organizational Citizenship Behavior and Emotional Intelligence of EFL Teachers in Saudi Arabia: Implications to Teaching Performance and Institutional Effectiveness. Arab World English Journal, 11 (4)3-14. DOI: https://dx.doi.org/10.24093/awej/vol11no4.1

- Mohamed H, El-Fattah A, Abd El-Hamid M, \& Mohamed W (2018): The Relationship between Quality of Work Life and Organizational Citizenship Behavior among Nurses at El-Mansoura Health Insurance Hospital. Zagazig Nursing Journal, 14(1), 148-159.

- Mohammad A, Saleem M, Al-Hawary S, AlSyasneh M, \& Alhajri T (2020): The influence of Internal Marketing Practices on the employees' intention to leave: A study of the private hospitals in Jordan. International Journal of Advanced Science and Technology, 29(5), 1174-1189.)

- Motalebi P \& Marşap A (2020): The role of Job satisfaction, and Organizational commitment as a determinant of organizational citizenship behavior among the workers of welfare organization. SSRG International Journal of Economics and Management Studies (SSRG-IJEMS), 7(1), 102112.

- Navis M, Widiastuti N, \& Sumardjo M (2020): Factors affecting organizational citizenship behavior on the environment of community organizations in Indonesia. Jurnal Aplikasi Manajemen, 18(3).

- Nawafleh A \& Alsafadi Y (2020): The effect of a high-commitment work system on improve organization citizenship behavior: An empirical study in Zain Telecom Company in Jordan. Asian Journal of Social Science and Management Technology, 2(4), 195-217.

- Norris S \& Porter T (2021): The influence of spirituality in the workplace and perceived organizational support on organizational citizenship behaviors for strategic success. In Research Anthology on Religious Impacts on Society (pp. 125). IGI Global. 
- Ozluk B \& Baykal U (2020): Organizational Citizenship Behavior among Nurses: The Influence of Organizational Trust and Job Satisfaction. Florence Nightingale Journal of Nursing, 28(3), 333-340. DOI: 10.5152/FNJN.2020.19108

- Pohjalainen S (2021): 'Freedom of choice': A case study of internal communication strategies and practices on marketing in the health care sector. Helsinki Metropolia University of Applied Sciences (Master of Health Care), Health Business Management. pp :( 1-72).

- Prabowo W (2020): Organizational Citizenship Behavior, Organizational Climate, and Employee Performance. Journal of Economics and Business, 3(4).

- Sahibzada U, Jianfeng C, Latif K, \& Sahibzada H (2020): Fueling knowledge management processes in Chinese higher education institutes (HEIs): the neglected mediating role of knowledge worker satisfaction. Journal of Enterprise Information Management. Vol. 33 No. 6. pp: (13951417).

- Santoso P, Asbari M, Siswanto E, \& Fahmi K (2020). The Role of Job Satisfaction and Organizational Citizenship Behavior on Performance: Evidence from Indonesian Teachers. International Journal of Social and Management Studies, 1(1), 22-31

- Sheeraz M, Ahmad U, Ishaq M, \& Nor K (2020): About moderating role of leader-member exchange between the relationship of organizational justice and organizational citizenship behavior. Pakistan Journal of Commerce and Social Sciences (PJCSS), 14(3), 635-660.

- Shrestha M \& Subedi D (2020): Organizational Citizenship Behavior among Teachers of Nepal: Did Locale Contribute it's in School Settings? American Journal of Economics and Business Management, 3(1), 1-23.

- Solihin I \& Manurung A (2020): Influence of Situational Leadership, Extrinsic Motivation, and Intrinsic Motivation on Organizational Citizenship Behavior (OCB) in State Civil Aparatures (ASN) In Local Government Pandeglang District of Banten Province. International Journal of Innovative Science and Research Technology, 5(2), 246-257.

- Thomas B \& Rodrigues A (2020): Internal Marketing and Brand Promise Delivery of Indian Public Sector Banks: A Causal Relationship Analysis. Indian Journal of Marketing, 50(10-11), 40-56.

- Uzonwanne F (2014): Organizational citizenship behaviour and demographic factors among oil workers in Nigeria. Journal of Humanities and Social Science, 19(8), 87-95.
- Uzonwanne F (2014): Organizational citizenship behavior and demographic factors among workers in Nigeria. Journal of Humanities and Social Science, 19(8), 87-95.

- Yeum M, Wee K, \& Bang W (2020): The Effect of Internal Marketing on Competitive Advantage as Organizational Coaching-The Mediating Effect of Service Innovation. Journal of System and Management Sciences, 10(1), 62-71.

- Yildiz A \& Suleyman E (2016): The Effect of Internal Marketing on Organizational Citizenship Behavior of Academic Staff in Higher Educational Institutions. Universal Journal of Educational Research; 4(5), 1122-1128. 